Rev. Tomasz Koztowski

The John Paul II Catholic University of Lublin

DOI: $10.15290 /$ rtk.2020.19.01

iD $0000-0002-3886-2787$

\title{
The Role of God's Word in Priestly Formation: Selected Issues
}

The Word of God is the foundation that enables a young man to establish a deep bond with Christ while following the path of priestly formation. Daily prayer based on profound meditation on God's word (lectio divina) helps a seminarian become rooted deeply in the Holy Scripture and to truly encounter Jesus in the books of the Gospel. The student also needs intellectual formation based on Holy Scripture in order to understand more the secrets of the Holy Scripture more profoundly and preach them in his ministry as reader.

Keywords: Word of God, Holy Scripture, lectio divina (divine reading), study, ministry of reader, education, formation, priesthood, seminary, student.

\section{Introduction: The Concept of "God's Word"}

For generations of Christians, the Word of God has been an inspiration, the foundation of the prayer, and a place to encounter God. The Bible, which contains the message of salvation addressed to man, "holds a privileged placed in the life of the Church." "The Church has always venerated the divine Scriptures just as she venerates the body of the Lord, since, especially in the sacred liturgy, she unceasingly receives and offers to the faithful the bread of life from the table both of God's word and of Christ's body".2

In contemporary culture, the word is understood simply phonetically as the way man expresses himself and by which he imparts himself to others. ${ }^{3}$ Through the word people express their thoughts, convey in-

$1 \quad$ H.Simon, "Przepowiadanie biblijne," in: J. Kudasiewicz ed., Biblia w nauczaniu chrześcijańskim, Lublin 1991, 58.

2 Second Vatican Council, Dogmatic Constitution on Divine Revelation Dei Verbum, 1967 (abbreviated hereafter as: DV), 21.

3 See A. Grabner-Haider, "Słowo," in: Praktyczny Stownik Biblijny, A. GrabnerHaider, ed., Warszawa 1999, 1204-1205. 
Theology of Spirituality

formation, and communicate. Biblical tradition perceives the word in a similar but much broader way. In Jewish tradition, in which the Old Testament took shape, the spoken word was understood as a separate entity endowed with a certain power. This attribute was particularly evident in the divine word. Human thoughts are also endowed with a certain power, which differed from the power of God's word. For the ancient Hebrews, even common words signified something greater than sounds that conveyed information. ${ }^{4}$ For example, the human word was particularly powerful when it conveyed a blessing or a curse. The power of these words is rooted in the power of the person who speaks them. Since God is almighty (see Luke 1, 37), His word has almighty power. The central idea of both the Old and New Testaments is the Word of God and His connection with revelation. ${ }^{5}$ In the books of the Old Testament, the "word of God" (Hebrew: "dewar elohim or dewar Adonai") means prophetic revelation. It also signifies the Law, the Decalogue, the Book of Deuteronomy or, simply, Sacred Scripture. ${ }^{6}$ The word of God (Hebrew "dewar") as understood by prophets is an event-that is, the word brings about a new event that always takes place in history. The word of God plays a special role in the life of a priest ${ }^{7}$. In his apostolic exhortation Gaudete et Exultate, Pope Francis recalls that: "devotion to the word of God is not simply one of many devotions, beautiful but somewhat optional. It goes to the very heart and identity of Christian life. The word has the power to transform lives". ${ }^{8}$

The word of God is an essential part of a man's spiritual formation during his preparation to enter the priesthood. In the Decree on Priestly Training Optatam Totius, Paul VI writes the following about spiritual formation: "The spiritual training [...] should be imparted in such a way that the students might learn to live in an intimate and unceasing union with the Father through His Son Jesus Christ in the Holy Spirit. Conformed to Christ the Priest through their sacred ordination they should be accustomed to adhere to Him as friends, in an intimate companionship, their whole life through". ${ }^{9}$ One cannot speak about a real priesthood without an authentic and deep spiritual life. The Conciliar Fathers give the following advice regarding students: "they should be

See A. J. Levoratti, Moc stowa Bożego, MKPŚ: 3.

See W. R. F. Browning, "Słowo Boże," in: W. R. F. Browning, Stownik biblijny, Warszawa 2009, 469.

See R. Rubinkiewicz, "Słowo Boże”, SB: 142-143.

See DV, 24.

Francis, Apostolic Exhortation Gaudete Et Exultate, 2018, 156.

Paul VI, Decree on Priestly Training Optatam Totius, 1965 (abbreviated hereafter as: OT), 8; John Paul II, Postsynodal Apostolic Exhortation Pastores Dabo Vobis, 1992 (abbreviated hereafter as: PDV), 45. 
taught to seek Christ in the faithful meditation on God's word" ${ }^{10}$. In his exhortation Verbum Domini, Pope Benedict and the Synod of Bishops "attributed particular importance to the decisive role that the word of God must play in the spiritual life of candidates for the ministerial priesthood" and state that the "Scripture should thus be the soul of [students'] theological formation"11. The Pope Emeritus also encourages those who are preparing for priesthood to establish and develop their personal relationship with the God's word. In the following section, he enumerates the foundations on which this deep relationship with God's word that forms the priest and guides his development throughout his ongoing formation should be based..$^{12}$

\section{Meditation: Lectio Divina as a Form of Prayer}

Pope Benedict devotes one part of Verbum Domini to the relationship with God's word that a student must foster within himself. In this section entitled "The word of God and candidates for Holy Orders," Benedict stresses the importance of lectio divina..$^{13}$ The Pope indicates that: "Those aspiring to the ministerial priesthood are called to a profound personal relationship with God's word, particularly in lectio divina, so that this relationship will in turn nurture their vocation: it is in the light and strength of God's word that one's specific vocation can be discerned and appreciated, loved and followed, and one's proper mission carried out, by nourishing the heart with thoughts of God, so that faith, as our response to the word, may become a new criterion for judging and evaluating persons and things, events and issues"14. Pope Francis adds that " $[t]$ he Church is young when she is herself, when she receives ever anew the strength born of God's word". ${ }^{15}$

The etymology of the expression lectio divina (divine reading) indicates the formative nature of God's word because those who engage in this practice take advantage of the opportunity to fully develop their religious life. The Church's awareness has always been accompanied

$10 \quad$ OT, 8.

11 Benedict XVI, Postsynodal Apostolic Exhortation Verbum Domini, 2010 (abbreviated hereafter as: VD), 82.

12 SeeJ.Wątroba, Permanentna formacjaduchowa kapłanów wświetle soborowych i posoborowych dokumentów Urzędu Nauczycielskiego Kościoła (1963-1994), Częstochowa 1999, 115.

13 For more information on lectio divina, see A. Siemieniewski, "Maryja zachowywała i rozważała wszystkie te sprawy w swoim sercu. Lectio divina drogą rozwoju duchowego kapłana", in: J. Kiciński, ed., Stowo Boże szkoła formacji kapłańskiej, Wrocław 2011. $\mathrm{VD}, 82$.

15 Francis, Postsynodal Apostolic Exhortation Christus Vivit, 2019, 35. 
by its conviction that the Holy Spirit spiritually directs lectio divina. ${ }^{16}$

Pope Benedict devoted a lot of texts to this form of Christian meditation in Verbum Domini. He writes that lectio divina is a fundamental part of the spiritual life of every believer and adds, "The word of God is at the basis of all authentic Christian spirituality" ${ }^{17}$ Furthermore, Benedict XVI quotes the Dogmatic Constitution Dei Verbum, which states: "they should gladly put themselves in touch with the sacred text itself, whether it be through the liturgy, rich in the divine word, or through devotional reading, or through instructions suitable for the purpose and other aids [...] And let them remember that prayer should accompany the reading of Sacred Scripture". ${ }^{18}$

In his apostolic letter Novo Millennio Ineunte, John Paul II also encourages the practice of lectio divina, writing: "It is especially necessary that listening to the word of God should become a life-giving encounter, in the ancient and ever valid tradition of lectio divina, which draws from the biblical text the living word which questions, directs and shapes our lives". ${ }^{19}$ In his exhortation Verbum Domini, Pope Benedict recalls what lectio divina is: the private or communal reading of a longer excerpt of Scripture as "God's word," which arises due to the inspiration of the Holy Spirit and later turns into meditation, prayer, and contemplation. This reading must be done with faith, and it must be uninterrupted, since this kind of reading is meditative and has the potential to turn into contemplation..$^{20}$

One of the most well known Polish biblical scholars, Fr. Józef Kudasiewicz, quoted the official document of the Pontifical Committee for the Celebration of the Great Jubilee of 2000, which encourages the practice of lectio divina: "According to this document, lectio divina is reading of the Gospel in a prayerlike manner. In Lectio divina we not only listen to and contemplate Jesus' words, we also consider these words the subject of our prayer and our acceptance of these words in our hearts guides us." ${ }^{21} \mathrm{He}$ adds that this type of prayer leads one to discover the Holy Spirit in the Holy Scripture.

Lectio divina consists of five steps: lectio, meditatio, oratio, contemplatio, and actio. ${ }^{22}$ In ancient and medieval times, the tradition of lectio

16 See A. Szewcin, I. Werbiński, Lectio divina, in: M. Chmielewski, ed., Leksykon duchowości katolickiej, Lublin - Kraków 2002 (LDK), 462-463.

$17 \quad \mathrm{VD}, 86$.

18 Ibid., 25.

$19 \quad$ John Paul II, Apostolic Letter Novo Millennio Ineunte, 2001, 39.

20 See J. Kudasiewicz, Odkrywanie Ducha Świętego. Medytacje biblijne, Kielce 1998, 52.

21 Ibid., 60.

22 See A. Szewcin, I. Werbiński, Lectio divina, 462. 
divina included the first four steps. Only recently was the fifth step - actio - added.

The first step of this practice begins with reading the sacred text in order to familiarize oneself with it. Benedict XVI suggests asking oneself the following question in order to encounter God in His word more profoundly: "[W] hat does the biblical text say in itself?". The Pope writes that: "Without this, there is always a risk that the text will become a pretext for never moving beyond our own ideas". ${ }^{23}$ Lectio is reading and, therefore, the starting point, since it begins with listening to what God is saying. One must read thoroughly in order to accomplish the first step effectively and fruitfully. This requires peace and quiet. Reading should also be done with patiens (patience) so that the text will permeate deeply into the soul..$^{24}$ Lectio is more about listening and understanding than of reflection. Therefore, during lectio, the reader should enter into contemplative peace and avoid rushing the process of prayer. ${ }^{25}$

Moreover, the first step of lectio divina requires certain amount of both time and space for reading Scripture.$^{26}$ During this step, one can refer to biblical commentary, which will provide explanations of more difficult scriptural passages. The excerpts, which are to be contemplated the following day, should be prepared the previous evening. ${ }^{27}$ Lectio consists in understanding a part of Scripture by finding other similar expressions, texts, and parallels within the Bible. ${ }^{28}$

After lectio comes meditatio - that is, meditation. Pope Benedict suggests that, during meditatio, one asks oneself: "[W]hat does the biblical text say to [me]?". ${ }^{29} \mathrm{He}$ further writes that: "Here, each person, individually but also as a member of the community, must let himself or herself be moved and challenged". ${ }^{30}$ In meditatio, the biblical text should be read even more slowly while carefully contemplating each sentence in order to enter one's heart and ask oneself: "How am I reacting to God's word which I am reading at this moment?" Such a prayer requires that one enter deeply into the human heart. ${ }^{31}$ In his indications regarding the second step of lectio divina, Reverend Krzysztof Wons writes: "if lectio

$23 \quad \mathrm{VD}, 87$.

See A. Cencini, Stowo Boże i formacja, Kraków 2006, 26.

See M. Margassi, Biblia i modlitwa, Kraków 2003, 154.

See I. Gargano, Zgtębianie Słowa Bożego, Kraków 2003, 34.

See J. Kudasiewicz, Odkrywanie Ducha Świętego, 59.

SeeS. Curro, R. Dimonte, Mtodziz Biblia. Poradnik dla duszpasterzy, katechetów $i$ animatorów, Kielce 2006, 25.

VD, 87.

30 Ibid.

$31 \quad$ See K. Wons, Jak żyć Słowem Bożym na co dzień?, Kraków 2002, 91. 
Theology of Spirituality is seeking, then meditatio, for which reading prepares us, is finding. Meditatio helps one find the Word's deepest meaning, Its power and light." ${ }^{32}$ At this stage, man permits God's word to enter into him and "reads" his life. This is the patient analytical and profound work that is the natural and necessary extension of reading. ${ }^{33}$ In this way, the text is assimilated so that the Word enters in and permeates the heart, revives it, and evokes a particular unrest. ${ }^{34}$ Through the process of meditatio, the spiritual man becomes "a living library." 35

The third step of lectio divina is oratio - that is, prayer. At this step, Pope Benedict invites the individual to ask the following question: "What do [I] say to the Lord in response to his word?". The Holy Father adds: "Prayer, as petition, intercession, thanksgiving and praise, is the primary way by which the word transforms us". ${ }^{36}$ When practiced properly, lectio and meditatio lead to the urge to pray. In this way, prayer is our response to God after listening to His word. Oratio is man's return to God in the words of Scripture, which are inspired by His Word. The transformation of God's word into prayer means looking at one's everyday life through the contemplated text. ${ }^{37}$ Under the Word's influence, one begins to tell God about one's experiences from the heart. Through the prayer of his heart, man directly expresses everything going on within himself. Thus, reading the Bible truly turns into a loving dialogue between the Creator and creation. Oratio comes from the heart; therefore, it is spontaneous. When speaking about oratio, Reverend Haręzga adds that "its form and content are revealed through the texts and through spiritual stirrings. This prayer is also involves comparing our life to the Word, to the extent to which each person finds and recognizes himself in [the Word]." 38 Every response to God expressed in prayer during oratio should be genuine and personal.

Contemplatio is the continuation of the previous two steps. Pope Benedict explains that, during contemplatio, "we take up, as a gift from God, his own way of seeing and judging reality, and ask ourselves what conversion of mind, heart and life is the Lord asking of us? [...] Contemplation aims at creating within us a truly wise and discerning vision of reality, as God sees it, and at forming within us "the mind of Christ" (1

32 K. Wons, Uwierzyć Jezusowi. Rekolekcje ze św. Markiem, Kraków 2004, 25.

See St. Haręzga, "Medytacja słowa Bożego podstawową modlitwą kapłana," in: J. Augustyn, ed., Sztuka bycia księdzem. Poradnik, Kraków 2010, 141.

See J. Kudasiewicz, Odkrywanie Ducha Świętego, 59.

See M. Margassi, Biblia i modlitwa, 161.

$\mathrm{VD}, 87$.

See G. Zevini, P. G. Cabra, Lectio divina na każdy dzień roku. Czas Adwentu, Warszawa 2009, 11-12. 
Cor 2:16)" 39 . Contemplatio is the highest degree of reading. As such, it should not be perceived as an extraordinary mystical grace from God, but as the proper crowning achievement of a genuine Christian life. Contemplation means loving God as the Truth and Life. ${ }^{40}$ The fourth step of lectio divina is not technique, but rather a gift of the Holy Spirit, which flows from the experience of a properly prayed prayer. In other words, "contemplation is the passive state of intimacy, in which God kindles the action. It is getting to know God through the experience of the heart." ${ }^{41}$ According to the Catechism of the Catholic Church: "Contemplative prayer is hearing the Word of God. Far from being passive, such attentiveness is the obedience of faith, the unconditional acceptance of a servant, and the loving commitment of a child". ${ }^{42}$ The Catechism of the Catholic Church further encourages lectio divina as a commonly practiced and proven method of prayer based on God's word. ${ }^{43}$

Lectio divina and meditation are preparatory steps for future pastoral work. The Decree on Priestly Training Optatam Totius conveys that students "are therefore to be prepared for the ministry of the word: that they might understand ever more perfectly the revealed word of God". ${ }^{44}$ The Conciliar Fathers encourage candidates for priesthood to "be taught to seek Christ in the faithful meditation on God's word, in the active participation in the sacred mysteries of the Church". ${ }^{45}$ In his exhortation on the formation of priests, Pastores Dabo Vobis, Pope John Paul II also writes: "Christian prayer, nourished by the word of God, creates an ideal environment where each individual can discover the truth of his own being and the identity of the personal and unrepeatable life project which the Father entrusts to him". ${ }^{46}$ John Paul II goes on to state that faithful contemplation of God's word is one of the "three great values and demands which further define the content of the spiritual formation of the candidate to the priesthood". ${ }^{47}$

VD, 87.

40 See J. Kudasiewicz, Odkrywanie Ducha Świętego, 59.

41 G. Zevini, P. G. Cabra, Lectio divina, 12-13.

Catechism of the Catholic Church, 2716.

See ibid., 1177, 2716.

OT, 4.

Ibid., 8.

PDV, 38.

47 Ibid., 46. 
Theology of

\section{Ratio Studiorum: Intellectual Formation Based on Holy Scripture}

In the Dogmatic Constitution on Divine Revelation Dei Verbum, the Second Vatican Council encourages a deeper understanding of Holy Scripture so that the Church continually feeds Her children with God's word. Dei Verbum encourages and supports studying the Bible: "Catholic exegetes then and other students of sacred theology, working diligently together and using appropriate means, should devote their energies, under the watchful care of the sacred teaching office of the Church, to an exploration and exposition of the divine writings. This should be so done that as many ministers of the divine word as possible will be able effectively to provide the nourishment of the Scriptures for the people of God, to enlighten their minds, strengthen their wills, and set men's hearts on fire with the love of God". ${ }^{48}$ The Conciliar Fathers encourage those who study the Bible because the Holy Scripture is "as it were, the soul of sacred theology". ${ }^{49}$

The aforementioned document indicates that all clergymen, deacons, including those who are preparing for priesthood, who are active in the ministry of the word need to study Holy Scripture, "so that none of them will become 'an empty preacher of the word of God outwardly, who is not a listener to it inwardly". ${ }^{50}$

When writing about intellectual formation of alumni in Pastores Dabo Vobis, Pope John Paul II indicates that "[i]ntellectual formation has its own characteristics, but it is also deeply connected with, and indeed can be seen as a necessary expression of, both human and spiritual formation. ${ }^{51}$ In the same paragraph, the Pope indicates: "In reality, through study, especially the study of theology, the future priest assents to the word of God, grows in his spiritual life and prepares himself to fulfill his pastoral ministry." He continues by emphasizing the importance of "the study of the word of God: the word set down in holy writ, celebrated and lived in the living tradition of the Church", 52 and he treats God's word as one of two ways of growing toward a mature reflection on the faith. ${ }^{53}$

In Verbum Domini, Pope Benedict makes a similar reflection, writing that lectio divina-the method prayer based on meditation on the Holy Scripture-must be an essential element of mandatory exegetical study during the priestly formation: "The Synod recommended that

\begin{tabular}{ll}
\hline 48 & DV, 23. \\
49 & Ibid., 24. \\
50 & Ibid., 25. \\
51 & PDV, 51. \\
52 & Ibid., 54. \\
53 & See ibid.
\end{tabular}


seminarians be concretely helped to see the relationship between biblical studies and scriptural prayer. The study of Scripture ought to lead to an increased awareness of the mystery of divine revelation and foster an Theology of Spirituality attitude of prayerful response to the Lord who speaks". ${ }^{54}$ Pope Benedict recommends that "great care should be taken to ensure that seminarians always cultivate this reciprocity between study and prayer in their lives" .55

Regarding exegetical and theological formation, the Pope indicates the following: "Care must be taken to ensure that the study of sacred Scripture is truly the soul of theology inasmuch as it is acknowledged as the word of God addressed to today's world, to the Church and to each of us personally". ${ }^{56}$ The Pope also emphasizes that these words arise from his concern for candidates for the priesthood. He adds: "As well as learning the original languages in which the Bible was written and suitable methods of interpretation, students need to have a deep spiritual life, in order to appreciate that the Scripture can only be understood if it is lived". 57

The Congregation for Christian Education's document Ratio Institutionis Sacerdotalis pro Polonia indicates that the most basic aim of the intellectual formation of students is to transmit the whole and unaltered teaching of the Church and God's Revelation recorded in Holy Scripture. ${ }^{58}$ The Decree on Priestly Optatam Totius training is mostly devoted to the Bible and encourages alumni to "draw out Catholic doctrine from divine revelation". ${ }^{99}$ The Conciliar Fathers also add: "The students are to be formed with particular care in the study of the Bible, which ought to be, as it were, the soul of all theology. After a suitable introduction they are to be initiated carefully into the method of exegesis; and they are to see the great themes of divine revelation and to receive from their daily reading of and meditating on the sacred books inspiration and nourishment". ${ }^{60}$ The same conciliar document supports and encourages the study of biblical languages and considers it to be most proper. ${ }^{61}$

Ratio studiorum - that is, the program of study in major seminaries in Poland-devotes a specific number of hours to courses on Scripture. The official six-year course of these studies includes a specific number of hours that must be devoted to studying the Bible. In theological studies, the biblical analysis is included in the field of biblical and patristic studies,

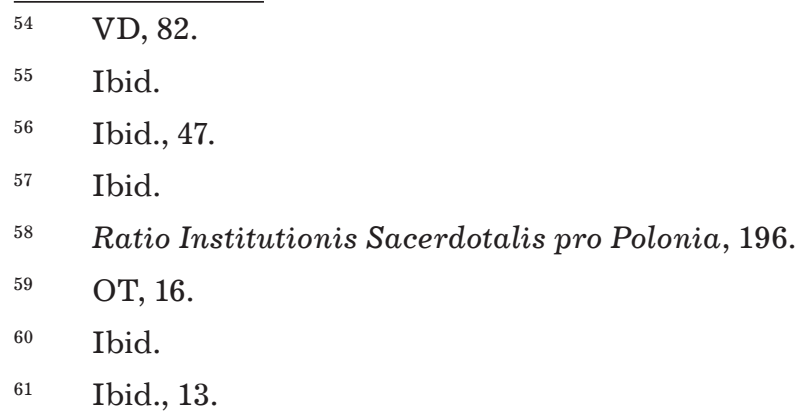


Theology of Spirituality

and students must attend 420 hours of lectures on these topics. The document indicates that the intellectual formation of the students should be devoted mainly to biblical studies: "The education must include all the books of the Holy Scripture, paying particular attention to the theology characteristic of each inspired book. [...] The aim of teaching the Bible is to acquaint the student with the Holy Books, instruct him to properly understand their content, and teach him to love God's word and express it in his daily reading of the Bible." ${ }^{2}$ The authors indicate that continual contact with Holy Scripture will enable priests to gain skills and transmit God's word to the faithful in their homilies and during catechesis.

In the summary on intellectual formation based on Holy Scripture, reverend Kudasiewicz points out that, in light of ecclesial documents, biblical formation should consist of four steps. Firstly, it should be modern-that is, it should introduce students to new exegetical methods. Secondly, it should be theological-that is, it should introduce the main topics of the Revelation. ${ }^{63}$ Thirdly, it should also be ascetic - that is, it should lead to the daily reading of Scripture. And finally, it should be applicable to pastoral work-that is, it should prepare seminarians for future biblical work. ${ }^{64}$

\section{The Ministry of Reader: Service and Implementation}

Seminarians should be encouraged to cleave to the Word of God in their intellectual formation based on Holy Scripture. The ministry of reader encourages this outcome because, by constantly meditating on God's word, the alumni are being formed by it during this important step in seminary formation. ${ }^{65}$ Paul VI expresses a similar idea in his Motu Proprio Ad Pascendum: "It is especially fitting that the ministries of reader and acolyte should be entrusted to those who, as candidates for sacred orders, desire to devote themselves to God and to the Church in a special way. [...] Both by study and by gradual exercise of the ministry of the word and of the altar, candidates for sacred orders should through intimate contact understand and reflect upon the double aspect of the priestly office. [...] In this way, candidates are to approach holy orders fully aware of their vocation, fervent in spirit, serving the Lord, constant in prayer, and aware of the needs of the faithful". ${ }^{66}$ Pope Paul

62 Ratio Institutionis Sacerdotalis pro Polonia, 163.

63 See Francis, Evangelii gaudium, 149.

$64 \quad$ See J. Kudasiewicz, Pismo Św. w teologii, 37.

65 A part of the prayer said by the bishop over those chosen for the ministry of reader, see: Konferenncja Episkopatu Polski, Ustanowienie lektorów i akolitów $i$ przyjęcie kandydatów do diakonatu i kaptaństwa oraz obrzędy święceń diakonów, kapłanów i biskupa, Warszawa 1977 (abbreviated hereafter as: ULA), 7.

Paul VI, Motu proprio Ad pascendum, 7. 
IV asserts that candidates for priesthood should be conscious of their true vocation before being ordained. When explaining the role of the reader, Paul IV points out that "[t]he reader is appointed for a function proper to him, that of reading the word of God in the liturgical assembly. Accordingly, he is to proclaim the readings from sacred scripture, except for the gospel in the Mass and other sacred celebrations" ${ }^{67}$

In the same document, Paul VI underscores that, "[b]efore anyone may be promoted to the diaconate, whether permanent or transitory, he must have received the ministries of lector and acolyte, and have exercised them for an appropriate time," so that he may "be better disposed for the future service of the word and the altar." In: fact the Church "considers it to be very opportune that both by study and by gradual exercise of the ministry of the word and of the altar, candidates for sacred orders should through intimate contact understand and reflect upon the double aspect of the priestly office. Thus it comes about that the authenticity of the ministry shines out with the greatest effectiveness. In this way the candidates come to sacred orders fully aware of their vocation, 'fervent in spirit, serving the Lord, constant in prayer and aware of the needs of the faithful' (Rom 12:11-13)" ${ }^{68}$ Intellectual formation based on the Bible helps seminarians fulfill the duties and conditions that Pope Paul VI places on them.

According to the General Instruction to the Roman Missal (2002): "The lector reads from the ambo the readings that precede the Gospel". ${ }^{69} \mathrm{In}$ order to emphasize the importance of readings from the Bible, every reading should take place at the proper pulpit. ${ }^{70}$ The reader is also privileged because he is permitted to carry the Book of the Gospels, which he raises in order to show God's People the Holy Scripture. ${ }^{71}$

The Theological and Pastoral Introduction to the Lectionary indicates that the reader is obliged to perform his proper function even if other ministers of a higher rank are present. ${ }^{72}$ The document also states that readers should be properly prepared for this ministry: "It is necessary that those who exercise the ministry of reader [...] be truly qualified and carefully prepared so that the faithful may develop a warm and living love for Scripture from listening to the sacred texts read". ${ }^{73}$ Therefore, the student who carries out the ministry of reader not only builds

67 Paul VI, Motu proprio Ministra quaedam, 5.

Paul VI, Motu proprio Ad pascendum; see Paul VI, Motu proprio Ministra quaedam, 11.

General Instruction to the Roman Missal 2002, 99, 196-198.

Ibid., 196-198.

71 See ibid., 194.

72 See Theological and Pastoral Introduction to the Lectionary, 51. 
Theology of Spirituality

his own faith and grows closer to the Holy Scripture, but he can also contribute to the development of the biblical formation of those who participate in the liturgy.

The Instruction on Liturgical Formation in Seminaries published by the Congregation for Catholic Education adds that, through the ministry of reader, "the students might experience the mystery of the Church as hierarchical, namely as consisting of a variety of members and distinct ministries". ${ }^{74}$ The document encourages students who are filled with the spirituality of their offices to manifest heir future priesthood as a form of service. ${ }^{75}$

In Pastores Dabo Vobis, John Paul II presents the ministry of reader also as a service. The Pope writes: "If the training is to be suitable, the different experiences which candidates for the priesthood have should assume a clear 'ministerial' character and should be intimately linked with all the demands that befit preparation to the priesthood". ${ }^{76}$

In Verbum Domini, Benedict XVI likewise refers to the ministry of reader. The Holy Father specifies that: "The Synod on the Eucharist had already called for greater care to be taken in the proclamation of the word of God". ${ }^{77}$ The document "echo[s] the Synod Fathers who once more stressed the need for the adequate training of those who exercise the munus of reader in liturgical celebrations and particularly those who exercise the ministry of Reader, which in the Latin rite is, as such, a lay ministry". ${ }^{78}$ This excerpt of Verbum Domini stresses the importance of preparing readers properly. Next, the John Paul II quotes The Theological and Pastoral Introduction to the Lectionary mentioned above.

During the ceremony for the installation of readers, the bishop stresses in his homily that "God the Father [...] gave the Church the obligation to preach the Gospel to all creation. This mission is particularly passed on bishops, priests and deacons. You, as the readers of God's word, will help them in fulfilling this obligation. [...] You will be reading God's word in the liturgical assembly." "79 Addressing future readers, the bishop adds: "while transmitting God's word to other people, in obedience to the Holy Spirit, take it yourselves and carefully meditate on it, in order to find in it joy and power. Preach our Saviour Jesus Christ with your everyday life." 80 The most important moment of the installation occurs at the end of the ceremony when those chosen for the ministry approach

\footnotetext{
74 Instruction on Liturgical Formation in Seminaries, 13.

75 Ibid.

$76 \quad$ PDV, 58.

77 VD, 58.

78 Ibid.

79 ULA, 6.

80 Ibid.
} 
the bishop who gives them the Holy Scripture saying, "Receive this book of the Holy Scripture and faithfully convey God's word in order to let it work stronger and stronger in human hearts." ${ }^{81}$ The service that each student assumes strengthens him in recognizing God's word more deeply, which then forms his personality as a future priest.

Therefore, the ministry of reader, the rite, and its implementation contribute significantly to the formation of future priests through the Word of God. As a reader, the seminarian proclaims God's word publically, becoming not only its spokesperson but also its witness who gives testimony through his own life and an example of what it looks like to cling to the truths revealed in Holy Scripture. The ministry of reader is the subsequent step and a conscious confirmation of the decision to become ordained. The respect that the student learns by reading the Bible awakens within him a greater concern to understand and study Holy Scripture further. While the bishop, on his part, appoints new readers and asks God to assist them with His grace so that, as they continually meditate on God's word, they are formed by it and faithfully convey it to others. ${ }^{82}$

\section{Conclusion}

God's word influences priestly formation in three ways: through meditation on God's word (lectio divina), intellectual formation based on Holy Scripture, and the ministry of reader. Lectio divina, of which Benedict XVI is a strong proponent in Verbum Domini, is an age-old method of meditating on the Word of God. Thanks to this method of prayer, future priests can come to know God's plan for their lives and are invited to generously respond to Him in their actio. Ratio studiorum is mainly devoted to the intellectual study of the Bible. Intellectual knowledge is a great foundation on which students can establish a deeper relationship with God's word. The ministry of reader is also an essential way in which a student receives God's word from his bishop and solemnly promises to proclaim it faithfully. In this way, he gains the strength that he will need for his further formation, since the Holy Scripture is the source of his relationship with Jesus. ${ }^{83}$

\section{Bibliography:}

1. Benedict XVI. Postsynodal Apostolic Exhortation Verbum Domini. 2010.

2. Browning, W. R. F. "Słowo." In: W. R. F. Browning, Stownik biblijny, Warszawa 2009.

3. Cencini, A. Stowo Boże i formacja. Kraków 2006.

82 Ibid.

83 Francis, Apostolic Exhortation Querida Amazonia, 2020, 107. 
Theology of Spirituality
4. Curro, S., Dimonte, R. Młodzi z Biblia. Poradnik dla duszpasterzy, katechetów $i$ animatorów. Kielce 2006.

5. Francis. Postsynodal Apostolic Exhortation Christus Vivit. 2019.

6. Francis. Apostolic Exhortation Evangelii Gaudium. 2014.

7. Francis. Apostolic Exhortation Gaudete Et Exultate. 2018.

8. Francis. Apostolic Exhortation Querida Amazonia. 2020.

9. Gargano, I. Zgłębianie Słowa Bożego w lectio divina. Kraków 2003.

10. Grabner-Haider, A. "Słowo." In: Praktyczny Słownik Biblijny. Edited by A. Grabner-Haider. Warszawa 1999, 1205-1208.

11. Haręzga, St. "Medytacja słowa Bożego podstawową modlitwą kapłana." In: Sztuka bycia księdzem. Poradnik. Edited by J. Augustyn. Kraków 2010, 137-145.

12. Haręzga, St. W biblijnej szkole życia. Materiaty do lectio divina. Poznań 2009.

13. John Paul II. Postsynodal Apostolic Exhortation Pastores Dabo Vobis. 1992.

14. John Paul II, Apostolic Letter Novo Millennio Ineunte. 2001.

15. Konferenncja Episkopatu Polski. Ustanowienie lektorów i akolitów $i$ przyjęcie kandydatów do diakonatu i kapłaństwa oraz obrzędy święceń diakonów, kapłanów i biskupa. Warszawa 1977.

16. Kudasiewicz, J. "Pismo Św. w teologii i duszpasterstwie. Rys historycznometodologiczny." In: Biblia w nauczaniu chrześcijańskim. Edited by J. Kudasiewicz. Lublin 1991, 17-40.

17. Kudasiewicz, J. Odkrywanie Ducha Świętego. Medytacje biblijne. Kielce 1998.

18. Levoratti, A. J. "Moc Słowa Bożego.” MKPŚ: 3-9.

19. Margassi, M. Biblia i modlitwa. Lectio divina. Kraków 2003.

20. Paul VI. Decree on Priestly Training Optatam Totius. 1965.

21. Paul VI. Motu Proprio Ad Pascendum. 1972.

22. Paul VI. Motu proprio Ministra quaedam. 1972.

23. Ratio Institutionis Sacerdotalis pro Polonia. 1998.

24. Rubinkiewicz, R. "Słowo Boże." SB: 142-143.

25. Siemieniewski, A. "Maryja zachowywała i rozważała wszystkie te sprawy w swoim sercu. Lectio divina drogą rozwoju duchowego kapłana." In: Stowo Boże szkoła formacji kapłańskiej. Edited by J. Kiciński. Wrocław 2011.

26. Simon, H. "Przepowiadanie biblijne.” In: Biblia w nauczaniu chrześcijańskim. Edited by J. Kudasiewicz. Lublin 1991, 49-84.

27. Second Vatican Council. Dogmatic Constitution on Divine Revelation Dei Verbum. 1967.

28. Szewcin, A., Werbiński, I. "Lectio divina.” In: Leksykon duchowości katolickiej. Edited by M. Chmielewski. Lublin - Kraków 2002, 462-463.

29. Wątroba, J. Permanentna formacja duchowa kapłanów $w$ świetle soborowych i posoborowych dokumentów Urzędu Nauczycielskiego Kościoła (1963-1994). Częstochowa 1999.

30. Wons, K. Jak żyć Stowem Bożym na co dzień? Kraków 2002.

31. Zevini, G., Cabra, P. G. Lectio divina na każdy dzień roku. Czas Adwentu. Warszawa 2009. 